\title{
The Unsuccessful Factors in Implementing Exclusive Breastfeeding Program in the Health Services Area of the Samatiga Community of West Aceh District - Indonesia
}

\author{
Lia Lajuna*, Maharani Maharani, Kartinazahri Kartinazahri, Noviyanti Noviyanti, Yusnaini Yusnaini, Ratna Dewi
}

Department of Midwifery, Polytechnic of Health, Ministry of Health, Aceh, Indonesia

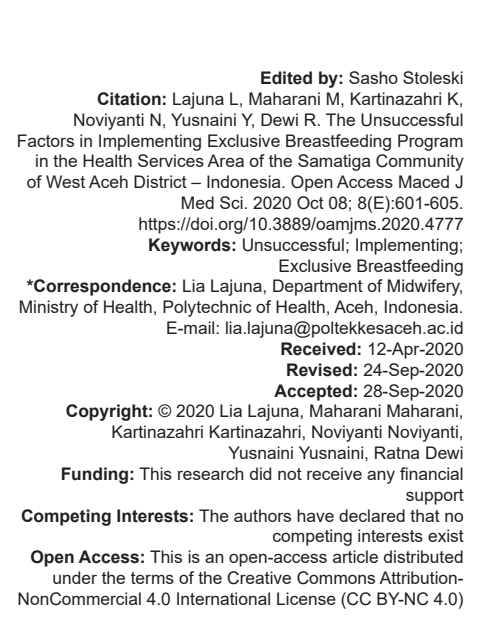

Abstract

BACKGROUND: Exclusive breastfeeding for babies from birth to 6 months is still not in accordance with the expected target. This happens because there are many factors that influence and are the background of the success of exclusive breastfeeding in the working area of the Samatiga Public Health Center in West Aceh Regency, Indonesia.

AIM: Analyzing the non-efficacy factors of exclusive breastfeeding in the Community Health Center Work area in Samatiga, West Aceh District, Indonesia.

METHODS: The study design used cross-sectional which was successfully carried out in September-December 2019 involving a population of breastfeeding mothers with infants aged between 7 and 12 months in the Samatiga Community Health Center, West Aceh District. The determination of the sample was chosen by purposive sampling technique to 98 breastfeeding mothers. The data analysis uses univariate and bivariate using Chi-square statistical test.

RESULTS: Based on the Chi-square correlation test, there was a significant relationship between the knowledge of breastfeeding mothers and the failure of exclusive breastfeeding $(0.000<\alpha 0.005$, RP $=39.952)$, breast problems $(0.000<\alpha 0.005), \mathrm{RP}=39.8000)$, and maternal occupation $([0.000<\alpha 0.005], \mathrm{RP}=3.878)$. The role of health workers $(0.000<\alpha 0.005), \mathrm{RP}=2.18333$, maternal health history $(\mathrm{p}=0.000<\alpha(0.05), \mathrm{RP}=33.000)$, infant health history $(0.000<\alpha 0.005), \mathrm{RP}=92.400$, and myths develop in the community $(0.000<\alpha 0.005), \mathrm{RP}=252.000$.

CONCLUSION: Factors related to the failure of exclusive breastfeeding in the work area of the Samatiga Health Center, West Aceh Regency include knowledge of breastfeeding mothers, breast problems, maternal work, the role of health workers, maternal health history, child health history, and myths that was developed in the community.

\section{Introduction}

Provision of exclusive breastfeeding Indonesia is still not according to the expected target. Riskesdas data for 2017 show that the coverage of exclusive breastfeeding increased twice as high as in 2015 , from $15.3 \%$ to $38 \%$ [1]. The data have not met the target of exclusive breastfeeding, which is $\geq 67 \%$. Nationally, there are only 73 districts or cities out of 497 districts or cities in Indonesia, around $14.7 \%$, who have achieved the target of exclusive breastfeeding [2]. The low level of exclusive breastfeeding is one of the triggers for the low nutritional status of infants and toddlers. Children's nutritional status is important and needs to be considered during their growth and development. Breastfeeding is exclusively beneficial for protecting children from a variety of acute and chronic diseases. The provision of exclusive breast milk must be accompanied by supplementary feeding of breast milk. Complimentary food mother's water plays a role to meet the nutritional needs of children who can no longer be fulfilled with breast milk alone. The provision and types of complementary foods
ASI are adjusted to the child's ability to digest so that malnutrition does not occur [3]. The practice of providing breast milk and MP-breast milk with nutritional status is closely related to the lack of food availability at the household level, care patterns, and inadequate health services. Another factor that is very influential on a child's nutritional status is the level of knowledge related to nutrition and the importance of nutrition maintenance since the fetus or the period of the first 2 years of life [4]. Some factors that influence the process of exclusive breastfeeding by mothers to infants are knowledge, education, income, and support of mythical health workers that develop in the community's attitude toward exclusive breastfeeding. Data from the West Aceh District Health Office revealed that there were 122 babies aged 7-12 months in 2016, who received 48 exclusively breastfed breast milk, while 81 were not exclusively breastfed. Furthermore, in 2017 there will be 120 babies aged 7-12 months, who receive exclusive breast milk of 54 babies and not exclusive breast milk of 56 babies [5]. The low level of exclusive breastfeeding is a serious problem in West Aceh district. For this reason, it is important to conduct a study to see the causes of the failure to 
provide exclusive breastfeeding in the working area of the district of West Aceh. The purpose of this research was to analyze the determinants of maternal failure in exclusive breastfeeding in the Samatiga Community Health Center, West Aceh District.

\section{Methods}

This study used a cross-sectional design method this study used a cross-sectional design. The research was conducted from September to December 2019.

The population of this study mother who was breastfeeding infants aged 7-12 months became the population in the working area of Samatiga Health Center, West Aceh District, while the selection of samples with purposive sampling techniques for 98 breastfeeding mothers. As for the sample criteria, breastfeeding mothers who have babies 7-12 months old, do not get exclusive breast milk and are willing to be respondents in this study. Data analysis uses univariable, and bivariable using Chi-square statistical test.

\section{Results}

\section{Univariate analysis}

The univariate analysis aims to describe the characteristics of each research variable and the results obtained are the frequency distribution and percentage of each variable. The results of data collection in this study are as follows (Table 1).

Table 1: Frequency distribution of mother's knowledge level of exclusive breastfeeding in the work area of Samatiga Health Center, West Aceh Regency in 2019

\begin{tabular}{llll}
\hline Variable & Indicators & Frequencies & $\%$ \\
\hline Knowledge level category & Less & 49 & 50.0 \\
& Medium & 19 & 19.4 \\
Breast problem & Better & 30 & 30.6 \\
Maternal work & Yes & 59 & 60.2 \\
& No & 39 & 39.8 \\
Breastfeeding Myth & Yes & 58 & 59.2 \\
& No & 40 & 40.8 \\
7 & Total & 98 & 100 \\
Maternal health Condition & Yes & 58 & 59.2 \\
& No & 40 & 40.8 \\
Baby Health Condition & & & \\
& Yes / Sick & 55 & 56.1 \\
Medical Roles (midwife) & No & 43 & 43.9 \\
The failure of exclusive breastfeeding & Total & 98 & 100 \\
& Yes/ sick & 61 & 62.2 \\
& No & 37 & 37.8 \\
& Receive advice & 38 & 38.8 \\
& No & 60 & 61.2 \\
& No & 60 & 61.2 \\
& Exclusive & 38 & 38.8 \\
\hline
\end{tabular}

The knowledge of breastfeeding mothers about the most exclusive breastfeeding is quite good knowledge of 49 respondents $(50.0 \%)$. Mothers with breast problems during breastfeeding were 59 respondents (60.2\%). The number of working breastfeeding mothers as many as 58 respondents $(59.2 \%)$, while the mother had history of illness as many as 55 respondents (56.1\%). Mothers who believed in myth were 58 respondents (59.2\%). Infants who have a history of disease as many as 61 respondents $(62.2 \%)$, the majority of mothers never received guidance from health workers (midwives), especially about exclusive breastfeeding as many as 60 respondents (61.2\%). Most of the mothers did not give exclusive breast milk $60(61.2 \%)$.

\section{Bivariate analysis}

Bivariate analysis was performed on two variables that allegedly had a relationship. In this study, the variables used are unpaired category variables so the bivariate analysis used is the Chi-square test (Table 2).

There is a significant relationship between breastfeeding mothers' knowledge and the exclusion of exclusive breast milk, as evidenced by the Chi-square test results obtained $p=0.000(p=0.000<\alpha=0.005)$. There is a significant relationship between breast problems with the failure of exclusive breastfeeding proven by the Chi-square test results obtained value of $p=0.000<\alpha=0.005$. Respondents who did not have breast problems had a 39.8000-fold chance of avoiding non-exclusive babies compared to respondents who had breast problems. There is a significant relationship between the work of mothers with the failure of exclusive breastfeeding proven by the Chi-square test results obtained value of $p=0.000<\alpha=0.005$. The existence of a significant relationship between the role of health workers with the failure of exclusive breastfeeding is evidenced by the Chi-square test results obtained ( $p=0.000<\alpha=0.005$ ). There is a significant relationship between maternal health history and the failure of exclusive breastfeeding, as evidenced by the Chi-square test results obtained $p=0.000<\alpha=0.005$ ). The existence of a significant relationship between a child's health history with the failure of exclusive breastfeeding is evidenced by the Chi-square test results obtained ( $p=0.000<\alpha=0.005)$. There is a significant relationship between myths and the failure of exclusive breastfeeding proven by the Chi-square test results obtained value of $p=0.000<\alpha=0.005$.

\section{Discussion}

Factors related to the failure of exclusive breastfeeding in the Samatiga Public Health Center Working Area of West Aceh Regency include knowledge of breastfeeding mothers, breast problems, maternal work, the role of health workers, maternal health 
Table 2: Analysis of Relationship between maternal knowledge, breast problems, occupation, the role of health workers, maternal health history, child health history, and myths to the failure of exclusive breast milk

\begin{tabular}{|c|c|c|c|c|c|c|c|c|}
\hline \multirow[t]{3}{*}{ Variable } & \multicolumn{4}{|c|}{ The success of exclusive breastfeeding } & \multirow{2}{*}{\multicolumn{2}{|c|}{ Total }} & \multirow[t]{3}{*}{$\mathrm{p}$-value } & \multirow[t]{3}{*}{ RR Cl 95\% } \\
\hline & \multicolumn{2}{|c|}{ Not exclusive } & \multicolumn{2}{|c|}{ Exclusive } & & & & \\
\hline & $\mathrm{n}$ & $\%$ & $\mathrm{n}$ & $\%$ & $\mathrm{n}$ & $\%$ & & \\
\hline \multicolumn{9}{|c|}{ Knowledge } \\
\hline Less & 42 & 42.9 & 7 & 7.1 & 49 & 50.0 & \multirow[t]{3}{*}{0.000} & \multirow[t]{3}{*}{39.952} \\
\hline Plenty & 13 & 13.3 & 6 & 6.1 & 19 & 19.0 & & \\
\hline Better & 5 & 5.1 & 25 & 25.5 & 30 & 30.6 & & \\
\hline \multicolumn{9}{|c|}{ Breast Problem } \\
\hline Yes & 59 & 60.2 & 0 & 0 & 59 & 60.2 & \multirow[t]{2}{*}{0.000} & \multirow[t]{2}{*}{39.8000} \\
\hline No & 1 & 1.0 & 38 & 38.8 & 39. & 39.8 & & \\
\hline \multicolumn{9}{|c|}{ Maternal Work } \\
\hline Yes & 43 & 43.9 & 15 & 15.3 & 58 & 59.2 & \multirow[t]{2}{*}{0.000} & \multirow[t]{2}{*}{3.878} \\
\hline No & 17 & 17.3 & 23 & 23.5 & 40 & 40.8 & & \\
\hline \multicolumn{9}{|c|}{ The Role of Health Officers } \\
\hline No & 59 & 60.2 & 1 & 59 & 60 & 61.2 & \multirow[t]{3}{*}{0.000} & \multirow[t]{3}{*}{2.18333} \\
\hline Yes & 1 & 1.0 & 37 & 37.8 & 38 & 38.8 & & \\
\hline Total & 60 & 61.2 & 38 & 38.8 & 98 & 100 & & \\
\hline \multicolumn{9}{|c|}{ Maternal Health History } \\
\hline yes & 50 & 51.0 & 5 & 5.1 & 55 & 56.1 & \multirow[t]{2}{*}{0.000} & \multirow[t]{2}{*}{33.000} \\
\hline No & 10 & 10.2 & 33 & 33.7 & 43 & 43.9 & & \\
\hline \multicolumn{9}{|c|}{ Baby Health History } \\
\hline Yes & 56 & 57.1 & 5 & 5.1 & 61 & 62.2 & \multirow[t]{2}{*}{0.000} & \multirow[t]{2}{*}{92.400} \\
\hline No & 4 & 4.1 & 33 & 33.7 & 37 & 37.8 & & \\
\hline \multicolumn{9}{|l|}{ Myth } \\
\hline Yes & 56 & 57.1 & 2 & 2.0 & 58 & 59.2 & \multirow[t]{2}{*}{0.000} & \multirow[t]{2}{*}{252.000} \\
\hline No & 4 & 4.1 & 36 & 36.7 & 40 & 40.8 & & \\
\hline
\end{tabular}

history, child health history, and myths that develop in the community. Maternal knowledge is related to the failure of exclusive breast milk $p=0.000<\alpha 0.005$ and the value of RP $=39.952$. Knowledge about the benefits of breastfeeding strongly influences the start and period of breastfeeding of a mother [6]. Lack of maternal knowledge about feeding practices for infants and children is one of the causes of the large number of babies weaned before the age of 6 months [7]. Mother's nutritional knowledge level is related to the child's nutritional status. Mothers with good knowledge tend to have children with good nutritional status because mothers know the nutritional needs of children, types, and sources of food to meet nutritional needs [8]. Good mother's knowledge is related to the success of exclusive breastfeeding for up to 6 months, although there are other factors that also influence [9], [10]. A person's level of nutritional knowledge influences attitudes and behaviors in choosing food, which determines whether or not someone easily understands the benefits of the nutritional content of the food consumed. Good nutritional knowledge is expected to influence good food consumption so that it can lead to normal nutritional status [11]. There is a positive relationship between knowledge and attitude in exclusive breastfeeding, which shows that if the mother has good knowledge, her attitude will be more especially positive in exclusive breastfeeding [12], [13]. There is a significant relationship between breast problems of breastfeeding mothers with the failure of exclusive breast milk where the results of $p=0.000<\alpha 0.005 \mathrm{RP}=39.8000$. The main cause of failure to provide breast milk is a problem in the breast. One of the problems that are often complained of by postpartum nursing mothers is the occurrence of blisters on nipples. The condition of the wounded nipples causes pain and even the blisters will bleed. Nursing mothers with excessive concern about body shape have a lower intention to provide exclusive breastfeeding [14]. A woman's shame when breastfeeding in front of others or in public places (public feeding) and their worry about changes in breast size (enlarged breasts) can cause a lack of duration of breastfeeding [15]. Breastfeeding mothers work is related to the failure of exclusive breastfeeding where the value of $p=0.000<\alpha 0.05, R P=3.878$. Working mothers have a tendency not to exclusively breastfeed [16], [17]. This is partly due to the short time off work, unsupported work environment, and short time off at work. An unsupported work environment is the factor most often associated with the high number of women workers who leave their obligations as a mother to breastfeed their children [18]. Mothers who do not work do have plenty of time to give exclusive breastfeeding but working mothers can also provide spare breast milk at home so that babies continue to get breast milk until the age of 6 months. A lactationfriendly work environment can help and create a sense of comfort for mothers to fulfill their obligations in taking care of the household when working, such as milking breast milk while working [19]. Health workers are associated with the failure of exclusive milk with a value of $0.000<\alpha(0.005), \mathrm{RP}=2.18333$. The longer duration of exclusive breastfeeding is significantly associated with the support of health workers in providing appropriate breastfeeding techniques [20]. The support of a capable husband and health worker increases the mother's confidence in her ability to provide adequate breast milk for her child [21]. Most who influence breastfeeding are mothers' perceptions of their husband's attitude [22]. Husbands and wives who join together during breastfeeding counseling can increase success in exclusive breastfeeding when compared to only involving mothers [23]. Maternal health history is related to the failure of exclusive breastfeeding with a value of $p=0.000<\alpha=0.005$. Physical preparation is important to prepare during breastfeeding. Mothers should do physical preparation to reduce the possibility of not releasing breast milk, adequate breast milk 
production, and prevent abnormalities in the breast. The Myth of Breastfeeding Mothers is related to the failure of exclusive breastfeeding where the results are $p=0.000$ $<\alpha 0.005$, RP $=252.000$. Myth often influences the failure of breast milk. There are a number of myths such as the mother believes that small breast size can cause a small amount of breast milk to come out. You also still believe that breastfeeding can change the shape of the breast and believe that breast milk that first comes out is dirty breast milk. The development of incorrect and inaccurate information in the community can make mothers less confident and decrease their enthusiasm for breastfeeding [24]. The health condition of babies is related to the failure of exclusive breastfeeding where the p-value results $(0.000<\alpha 0.005), \mathrm{RP}=92.400$ Health conditions of a baby can affect breastfeeding exclusively as babies have diarrhea every time they get breast milk, babies who suffer from congenital diseases because they cannot receive lactose, and babies born with physical conditions such as cleft lip, cleft palate sky, and others [25].

\section{Conclusion}

There are factors that are related to the failure of the provision of exclusive breastfeeding in the Samatiga Health Center Work Area, West Aceh Regency, namely, knowledge of breastfeeding mothers, breast problems, mother's work, the role of health workers, maternal health history, child health history, and myths that develop in the community.

\section{References}

1. Kementrian Kesehatan Republik Indonesia. Profil Kesehatan Indonesia. Jakarta: Kementrian Kesehatan Republik Indonesia; 2017. https://doi.org/10.6066/itip.2013.24.2.121

2. Departemen Kesehatan. Buku Panduan Manajemen Laktasi: Direktorat Gizi Masyarakat. Jakarta: Depkes, Departemen Kesehatan; 2016.

3. Shrimpton R, Victora CG, De Onis M, Lima RC, Blössner M, Clugston G. Worldwide timing of growth faltering: Implications for nutritional interventions. Pediatrics. 2001;107(5):E75. https:// doi.org/10.1542/peds.107.5.e75

PMid:11331725

4. Akeredolu IA, Osisanya JO, Seriki-Mosadolorun JS, Okorafor U. Mothers' nutritional knowledge, infant feeding practices and nutritional status of children (0-24 months) in Lagos State, Nigeria. Eur J Nutr Food Saf. 2014;4(4):364-7. https://doi. org/10.9734/ejnfs/2014/7604

5. Dinas Kesehatan Aceh Barat. Data Kesehatan Masyarakat. Meulaboh, Indonesia: Dinkes, Dinas Kesehatan Aceh Barat; 2018. https://doi.org/10.32672/makma.v2i2.1301

6. Pearce J, Taylor MA, Langley-Evans SC. Timing of the introduction of complementary feeding and risk of childhood obesity: A systematic review. Int J Obes (Lond). 2013;37(10):1295-306. https://doi.org/10.1038/ijo.2013.99 PMid:23736360

7. Egata G, Berhane $Y$, Worku A. Predictors of non-exclusive breastfeeding at 6 months among rural mothers in east Ethiopia: A community-based analytical cross-sectional study. Int Breastfeed J. 2013;8:8. https://doi.org/10.1186/1746-4358-8-8

8. Williams P. What is Social Support? A Grounded Theory of Social Interaction in the Context of the New Family. Adelaide, AU: University of Adelaide; 2005

9. Gijsbers B, Mesters I, Knottnerus JA, Van Schayck CP. Factors associated with the initiation of breastfeeding in asthmatic families: The attitude-social influence-self-efficacy model. Breastfeed Med. 2006;1(4):236-46. https://doi.org/10.1089/ bfm.2006.1.236

PMid:17661604

10. Ansari S, Abedi P, Hasanpoor S, Bani S. The effect of interventional program on breastfeeding self-efficacy and duration of exclusive breastfeeding in pregnant women in Ahvaz, Iran. Int Sch Res Notices. 2014;2014:510793.

PMid:27379293

11. Ajao KO, Ojofeitimi EO, Adebayo AA, Fatusi AO, Afolabi OT. Influence of family size, household food security status, and child care practices on the nutritional status of under-five children in Ile-Ife, Nigeria. Afr J Reprod Health. 2010;14(4):117-26. PMid:21812205

12. Foo LL, Quek SJ, Ng SA, Lim MT, Deurenberg-Yap M Breastfeeding prevalence and practices among Singaporean Chinese, Malay and Indian mothers. Health Promot Int. 2005;20(3):229-37. https://doi.org/10.1093/heapro/dai002 PMid: 15814526

13. Uchendu UO, Ikefuna AN, Emodi IJ. Exclusive breastfeedingthe relationship between maternal perception and practice. Niger J Clin Pract. 2009;12(4):403-6. PMid:20329681

14. Barnes J, Stein A, Smith T, Pollock JI. Extreme attitudes to body shape, social and psychological factors and a reluctance to breast feed. ALSPAC Study Team. Avon Longitudinal Study of Pregnancy and Childhood. J R Soc Med. 1997;90(10):551-9. https://doi.org/10.1177/014107689709001007 PMid:9488013

15. Brown A, Rance J, Bennett P. Understanding the relationship between breastfeeding and postnatal depression: The role of pain and physical difficulties. J Adv Nurs. 2016;72(2):273-82. https://doi.org/10.1111/jan.12832

PMid:26494433

16. Lene AK, Lande B, Cecilie NO, Frost LA. Factors associated with exclusive breast-feeding and breastfeeding in Norway. Public Health Nutr. 2010;13(12):2087-96. https://doi.org/10.1017/ s1368980010002156

17. Forster DA, McLachlan HL, Lumley J. Factors associated with breastfeeding at six months postpartum in a group of Australian women. Int Breastfeed J. 2006;1:18. PMid:170346

18. Asosiasi Ibu Menyusui Indonesia. Lingkungan Kerja Ramah Laktasi: Pedoman Untuk Perusahaan. Jakarta: Asosiasi lbu Menyusui Indonesia; 2013. https://doi.org/10.22146/jkn.9848

19. Montgomery KS, Best M, Aniello TB, Phillips JD, HatmakerFlanigan E. Postpartum weight loss: Weight struggles, eating, exercise, and breast-feeding. J Holist Nurs. 2013;31(2):129-38. https://doi.org/10.1177/0898010112464120 PMid:23175169

20. Cernadas JM, Noceda G, Barrera L, Martinez AM, Garsd A. Maternal and perinatal factors influencing the duration of exclusive breastfeeding during the first 6 months of life. J Hum Lact. 
2003;19(2):136-44. https://doi.org/10.1177/0890334403253292 PMid: 12744530

21. Mannion CA, Hobbs AJ, McDonald SW, Tough SC. Maternal perceptions of partner support during breastfeeding. Int Breastfeed J.2013;8(1):4. https://doi.org/10.1186/1746-4358-8-4 PMid:23651688

22. Arora S, McJunkin C, Wehrer J, Kuhn P. Major factors influencing breastfeeding rates: Mother's perception of father's attitude and milk supply. Pediatrics. 2000;106(5):E67. https:// doi.org/10.1542/peds.106.5.e67
PMid:11061804

23. Susin LR, Giugliani ER. Inclusion of fathers in an intervention to promote breastfeeding: Impact on breastfeeding rates. J Hum Lact. 2008;24(4):386-92. https://doi. org/10.1177/0890334408323545

PMid: 18784322

24. Indarti L. Tahun Ikatan Bidan Indonesia Bidan Menyongsong Masa Depan. Jakarta: Pengurus Pusat Ikatan Bidan Indonesia; 2007. https://doi.org/10.31000/jkft.v3i2.1284

25. Prawirohardjo S. IImu Kebidanan. Jakarta: Bina Pustaka Sarwono Prawirohardjo; 2010. 